\title{
Minimally invasive microscopically assisted lumbar discectomy using the METRx X-Tube system
}

\author{
Minimalnie inwazyina dyscektomia lędźwiowa przy użyciu systemu METRx X-Tube \\ i mikroskopu operacyinego
}

Przemysław Kunert, Paweł Kowalczyk, Andrzej Marchel

Katedra i Klinika Neurochirurgii, Warszawski Uniwersytet Medyczny

Neurologia i Neurochirurgia Polska 2010; 44, 6: 554-559

\begin{abstract}
Background and purpose: Lumbar discectomy with the METRx X-Tube system and operating microscope is a modification of microendoscopic discectomy. The aim of this study was to describe this method and present the results of treatment of the first 13 patients.

Material and methods: Under general anaesthesia and fluoroscopic guidance, a guidewire was placed over the inferior aspect of the superior lamina. A $2.5-3 \mathrm{~cm}$ midline skin incision was made, followed by paramedian lumbar fascia incision. Then, dilators were sequentially introduced (musclesplitting approach). Finally, a tubular retractor was fixed directly over the interlaminar space. Further stages of the procedure were performed using an operating microscope and standard microdiscectomy equipment. The first 13 consecutive patients operated on using this method were analysed. Twelve patients were operated on at one level and 1 at two levels. Disc herniation was centro-lateral in 10 cases, lateral in 2 and central (broad-based) in 2 patients.

Results: Regression of radicular pain was noted in all patients. No postoperative complications were observed except for prolongation of wound healing in 2 patients. According to modified MacNab criteria, excellent late outcome was achieved in 8 patients and good in 4 patients. There were no cases of recurrent radicular pain or need for surgical revision for herniation recurrence. One patient was reoperated on because of low back pain (implantation of an interspinous spacer).
\end{abstract}

\section{Streszczenie}

Wstęp i cel pracy: Dyscektomia lędźwiowa przy użyciu systemu METRx X-Tube i mikroskopu operacyjnego jest modyfikacją mikrodyscektomii polegającą na wykorzystaniu rozwieracza międzymięśniowego stosowanego wcześniej w metodzie mikroendoskopowej i zamianie podglądu endoskopowego na mikroskopowy. W pracy opisano powyższą metodę i zaprezentowano wyniki leczenia pierwszych 13 chorych.

Materiał i metody: W znieczuleniu ogólnym i pod kontrolą fluoroskopii umieszczano metalową prowadnicę tuż nad dolnym brzegiem łuku górnego kręgu. Skórę nacinano na długości 2,5-3 cm w linii środkowej, natomiast powięź lędźwiową paramedialnie. Następnie wprowadzano kolejno rozszerzadła METRx X-Tube poprzez mięśnie przykręgosłupowe (bez podokostnowego odwarstwienia). Po uzyskaniu ostatecznego kanału roboczego o średnicy 2,4 cm, bezpośrednio nad przestrzenią międzyłukową umieszczano cylindryczny rozwieracz. Dalszą część zabiegu przeprowadzano w asyście mikroskopu operacyjnego, narzędziami stosowanymi w mikrodyscektomii. U 12 chorych usunięto wypadnięty sekwestr z jednej przestrzeni, a u jednego na dwóch poziomach. W 10 przypadkach przepuklina była centralno-boczna, w 2 przypadkach centralna (szerokopodstawna), w kolejnych 2 przypadkach w zachyłku bocznym.

Wyniki: U wszystkich chorych bezpośrednio po operacji uzyskano ustąpienie bólów korzeniowych. Nie stwierdzono

Correspondence address: Przemysław Kunert, Katedra i Klinika Neurochirurgii, Warszawski Uniwersytet Medyczny, ul. Banacha 1 A, 02-097 Warszawa, fax + 2265836 53, e-mail: pkunert@wp.pl

Received: 24.02.2010; accepted: 31.08.2010 
Conclusions: Microscopically assisted lumbar discectomy using the METRx X-Tube system seems to be safe and effective. This method combines the advantages of modern minimally invasive techniques while avoiding the limitations of endoscopy.

Key words: lumbar disc herniation, microdiscectomy, minimally invasive spine surgery.

\section{Introduction}

Microdiscectomy remains the gold standard in the treatment of lumbar disc disease. Despite the fact that this technique has relatively low invasiveness and proven high efficacy, the development of neurosurgery over the last several years points to further minimization of the surgical approach [1]. Thus, a number of minimally invasive surgical techniques are currently being used in the treatment of lumbar disc disease. Endoscopic discectomy is one of them [2-4]. Another one is microendoscopic discectomy as described by Foley and Smith $[5,6]$. This method uses standard instrumentation for microdiscectomy while remaining a minimally invasive technique owing to the narrow, 'transdermal' access (without surgical dissection of successive layers) along with an endoscopic visualization.

The METRx system (Medtronic, Sofamor Danek) was initially used solely with endoscopic visualization but subsequently it was adapted for the operating microscope. This adjustment arose from the limitations of endoscopic visualization as well as neurosurgeons' inclination toward use of the microscope $[1,7,8]$. While the METRx system allows a view of the operative field through tubular retractors of equal diameter throughout, the METRx X-Tube system was enhanced with a retractor that widens at its distal end. It provides a wider view of the operative field (with minor skin incision preserved) that enables a more extensive spectrum of surgery, e.g. spinal instrumentation [9].

The aim of the following study is to describe the method and to present the outcome of the first 13 con- powikłań pooperacyjnych z wyjątkiem przedłużonego gojenia rany pooperacyjnej u 2 chorych. W ocenie odległej, zgodnie ze zmodyfikowanymi kryteriami MacNaba, wynik bardzo dobry uzyskano u 8 i dobry u 4 pacjentów. Jeden pacjent był ponownie operowany z powodu zespołu przeciążeniowego - implantowano stabilizator międzywyrostkowy. U żadnego pacjenta nie zaobserwowano nawrotowych bólów korzeniowych ani konieczności ponownej operacji z powodu nawrotowej przepukliny.

Wnioski: Dyscektomia lędźwiowa przy użyciu systemu METRx X-Tube i mikroskopu operacyjnego wydaje się skuteczną i bezpieczną metodą leczenia, łączącą zalety nowoczesnych minimalnie inwazyjnych technik operacyjnych, ale bez ograniczeń wynikających z podglądu endoskopowego.

Słowa kluczowe: dyskopatia lędźwiowa, mikrodyscektomia, minimalnie inwazyjna chirurgia kręgosłupa.

secutive patients. On top of that, we wanted to stress the differences between this technique and endoscopic discectomy described by Destandau $[2,3]$ that was recently clinically evaluated by Łysoń et al. [4].

\section{Material and methods}

A retrospective analysis of the first 13 consecutive patients who underwent minimally invasive lumbar discectomy with the METRx X-Tube and operative microscope for a lumbar disc disease between November 2005 and January 2006 was performed. At the same time, other patients in our department who suffered from lumbar disc herniation were operated on with classic microdiscectomy owing to objective reasons. Nonetheless, the qualification criteria in our cohort were analogous to classic microdiscectomy patients. Patients with herniated lumbar discs qualified for surgery when they had presented either with radicular pain refractory to conservative treatment or with progressive neurological deficits. Similarly to classic microdiscectomy patients with lateral, centro-lateral and central (broad-based) disc herniations were eligible.

Our cohort included 8 women and 5 men aged 18 to 50 years (mean, $34 \pm 10$ ). On admission, lumbosacral pain was present in 10 patients, radicular pain in 13 (bilateral in 1 case), foot paresis in 2 and hypoaesthesia in 5 patients. None of them had any sphincter disturbances.

Twelve patients had single level discectomy; 1 patient had surgery at 2 levels. In 10 cases disc herniations were centro-lateral, in 2 solely in the lateral recess; 2 patients 
had central (broad-based) herniation. In 10 cases level $\mathrm{L} 5 / \mathrm{S} 1$ and in $4 \mathrm{~L} 4 / 5$ were involved.

Surgery was performed under general anaesthesia, in the prone position. A proper level was initially identified under fluoroscopy with a guidewire (a K-wire) placed over the junction between the lamina and intervertebral joint process superior to the intervertebral space. A $2.5-3 \mathrm{~cm}$ midline skin incision over the guidewire insertion site was subsequently made, followed by a paramedian lumbar fascia incision. A guidewire was then used to sequentially introduce dilatators through the perispinal muscles under constant fluoroscopic guidance (without subperiosteal dissection). Upon achievement of a working canal of $2.4 \mathrm{~cm}$ in diameter a tubular retractor was introduced directly over the interlaminar space (Fig. 1). The 'X-tube' retractor used for the procedure upon dilation has a higher distal diameter in comparison to the proximal one and is equipped with an independent light source. After that, adjacent laminas' edges and ligamentum flavum were visualized. Further stages of the procedure were performed under

A

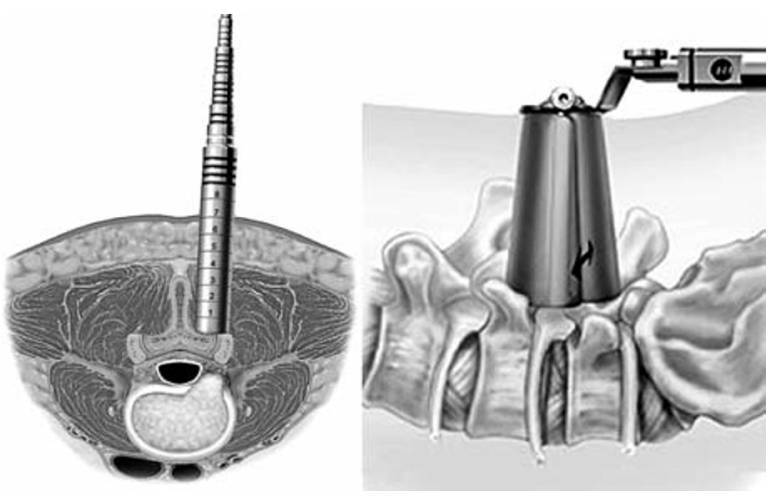

Fig. 1. (A) muscle-splitting approach is performed using a series of sequential dilators; ( $\mathrm{B}$ ) tubular retractor ('X-tube') is introduced and expanded at the distal end (courtesy of Medtronic Poland Sp. z 0.0., with permission) operating microscope control with standard microsurgical tools and bone rongeurs used for microdiscectomy.

Outcome was evaluated at discharge and in the longterm from ambulatory charts and via a questionnaire performed over the phone in October 2008. Eventually we managed to assemble reliable data for a long-term outcome assessment in 12 patients. The follow-up period varied from 20 to 22 months and averaged 21 months after surgery. Outcome was appraised based on modified MacNab criteria (Table 1).

\section{Results}

Duration of the surgery typically varied from 0.5 to 2 hours (mean, 1.3). None of the cases required conversion to a classic, open technique. Neither neurological nor septic complications, and no postoperative liquorrhoea were seen. Two patients suffered from prolonged wound healing. It was attributable to unduly short skin incision that resulted in excessive tension on wound edges and secondary necrosis. Six patients were discharged 1 day, 6 patients 2 days, and 1 patient 3 days after the operation. In the early postoperative period complete resolution of radicular pain in all 13 patients was achieved. Foot paresis diminished in 1 patient and hypoesthesia in 2 out of 5 patients.

Satisfactory long-term outcome has been achieved in all 12 patients with available catamnestic data. A single patient, whose data were not available, had no neurological deficits prior to and after surgery and was discharged home in a very good condition with no radicular symptoms. During 20-22 months of follow-up we noticed further decline of neurological deficits: foot paresis subsided in both patients and hypoesthesia in 4 out of 5 patients. According to modified MacNab criteria, excellent outcome was achieved in 8 and good (occasional lumbosacral pain) in the remaining 4 patients, among whom 1 underwent subsequent surgery due to low back syndrome (DIAM interspinous spacer

Table 1. Late outcome according to modified MacNab criteria

\begin{tabular}{|llc|}
\hline Outcome & Description & No. of patients \\
\hline Excellent & Free of pain, no restriction of mobility, able to return to normal work and activities & 8 \\
\hline Good & Occasional non-radicular pain, relief of presenting symptoms, able to return to modified work & 4 \\
\hline Fair & $\begin{array}{l}\text { Continued objective symptoms of root involvement, additional operative intervention needed } \\
\text { at the index level }\end{array}$ & 0 \\
\hline Poor & $\begin{array}{l}\text { Continued objective symptoms of root involvement, additional operative intervention needed } \\
\text { at the index level, irrespective of repeat or length of postoperative follow-up }\end{array}$ & 0 \\
\hline
\end{tabular}


implanted). None of the patients presented with recurrent radicular pain. Similarly, none of them required surgery for recurrent disc herniation (Table 1).

\section{Discussion}

The last decades have brought a rapid development of minimally invasive techniques in spine surgery. The inclination toward minimization of surgical interventions in this field originates from both patients' benefits (minimal perioperative injury and postoperative pain) and economic benefits (shorter hospitalization and health-related work absenteeism). Foley and Smith described microendoscopic discectomy (MED) in 1997 $[5,6]$. This surgical technique uses a system of dilatators that enables a muscle-split approach to the interlaminar space with subsequent use of a tubular retractor along with an endoscopic visualization. Further stages of the procedure are performed under an endoscopic visualization on the monitor with microsurgical tools similar to those used for a standard microdiscectomy.

The ability to use microsurgical tools in one, relatively wide working channel instead of using custom designed instruments within a few narrow channels is the main difference between microendoscopic and endoscopic technique. Consequently, the MED system, owing to neurosurgeons' preference for the microscope view as well as the limitations of endoscopic visualization (i.e. 2D image and relatively long learning curve), led toward the replacement of the endoscope with the microscope $[1,6,7]$. Even though the microscopic visualization has its own limitation, with the visualization constrained by the edges of the retractor, the $3 \mathrm{D}$ images facilitate anatomical discernment and faster preparation [1].

The METRx system includes cylindrical retractors of equal diameter throughout, while the X-Tube retractor widens toward its distal end. It enables a wider view of the operative field while the skin incision remains small. This modification also makes possible a wider range of surgical procedures. On the other hand, additional retraction during longer procedures might result in more pronounced muscle injury.

Theoretically, a muscle-split approach results in a smaller degree of muscle denervation and, in comparison to a classic approach, does not result in interspinous and supraspinous ligaments' traction that might impair the stability of the spinal functional complex [8]. To our best knowledge no prospective, randomized studies evaluating whether the muscle-splitting approach is less trau- matic than a traditional subperiosteal approach have been published so far. There are only a few reports that attempt to objectively evaluate the degree of tissue injury and inflammatory response following muscle-splitting and traditional approaches. Sasaoka et al. analysed serum levels of phosphocreatine kinase, $\mathrm{C}$-reactive protein and interleukin-6 and -10. Patients after microendoscopic discectomy had a significantly lower level of interleukin-6 $24 \mathrm{~h}$ after surgery when compared to patients after classic microdiscectomy. More pronounced differences were present when the reference group comprised patients after laminotomy [10]. Shin et al., on the other hand, found lower levels of lactate dehydrogenase and phosphocreatine kinase (as markers of muscle injury) after microendoscopic discectomy when compared to a classic microdiscectomy [11]. Clinical evaluations suggest that the muscle-splitting approach reduces postoperative pain and use of analgesic medications after surgery $[10,12]$. The aforementioned studies involved the use of tubular retractors with equal diameter throughout. Lower levels of serum creatine kinase were reported after spinal stabilization with the $\mathrm{X}$-tube retractor when compared to open surgery [9].

The idea of the muscle-splitting approach does not pertain solely to simple discectomy. METRx system use (with endoscopic or microscopic assist) has been described in decompressive surgery in recurrent disc herniation [13], the translaminar approach to herniated discs [14], far-lateral disc herniations [15,16] and minimally invasive spinal instrumentations [17]. Bilateral lumbar decompression in degenerative stenosis is feasible as well, from a unilateral approach. In this particular case, invasiveness of the procedure is abridged even more, for there is no intervention within the perispinal muscles on the contralateral side [18]. Conversely, the METRx X-Tube system makes possible spinal instrumentations. The majority of reports describe its use for lumbar intervertebral stabilizations (PLIF, TLIF) [19]. Its usefulness and safety is particularly stressed in spinal stabilizations for selected cases $[20,21]$. Case reports of $\mathrm{X}$-tube use for syringomyelia, tethered cord and spinal tumours also exist [22-24].

In our experience, the METRx X-Tube system proved its usefulness, efficacy and convenience. There was no need to convert the approach to the classic one in any of the cases, despite the fact that these were our first operations with the system. None of our patients required reoperation caused by incomplete decompression or recurrent disc herniation. We encountered no technical difficulties with removal of broad-based discs 
or intervertebral space penetration with curved instruments. Prolonged wound healing with excessive scarring was the single obstacle we came across. It resulted from a skin incision that was too short and led to necrosis of the wound edges caused by retractor compression. A very short skin incision, made for aesthetic reasons, might thus give the opposite effects. To avoid these complications, the skin incision should be slightly longer than the retractor diameter.

In comparison, Łyson et al. reported that patients operated on with the Destandau endoscopic approach required conversion of the approach to the classic open one in $41 \%$ of cases (31 out of 76). Moreover, among the patients who underwent solely endoscopic discectomy, $11 \%$ (5 out of 45 ) had indications for early reoperation [4]. The authors stress that the endoscopic approach ensures comparable outcome to a classic microdiscectomy in a well-selected group of patients with postero-lateral disc herniations. In their opinion, endoscopic discectomy has other limitations as well, namely: difficult anatomical orientation on approach to the ligamentum flavum (resulting from a 2D image) or difficult nerve root retraction when it is stretched on the disc sequester since spatula movements require manipulations of the entire endoscope. On top of that, intervertebral space penetration is limited by the fact that only straight tools are available. Still, the biggest problem stems from the fact that this approach requires an entirely new surgical technique; in particular, one has to familiarize oneself with a variable quality two-dimensional image on the monitor. The intricate and time-consuming 'learning curve' in endoscopy has been pointed out by others as well $[4,25]$. The METRx system with microscopic visualization requires additional training in order to get acquainted with the new approach to the spine, but it pays back later on with the ability to use this system in more advanced surgery [26].

In our experience the METRx X-Tube system does not hold limitations similar to the endoscopic approach. The 'X-Tube' retractor has a single working channel with a distal diameter wider than the proximal one, which is opposite to the Destandau endoscope that narrows distally. It ensures a relative ease of movements in the operative field and enables the use of curved instruments (Fig. 1B). Even with non-expandable retractors one can efficiently remove loose, dorsally or caudally migrating sequesters, central, broad-based or foraminal discs, similar to classic microdiscectomy $[7,12]$.

Łyson et al. discharged their patients 2 or 3 days after surgery, while patients in our cohort were discharged within 1 or 2 days after surgery. The skin incision required in the endoscopic Destandau method varied from 1.5 to $2 \mathrm{~cm}$, while in our series it varied from 2.5 to $3 \mathrm{~cm}$. One can conclude then that these results are comparable; moreover, a 'traditional' microdiscectomy gives similar results for these categories. As a rule, we discharge patients after classic microdiscectomy within 24 hours after surgery. Currently, the outcome of microdiscectomy is so good that it is very difficult to improve it [1,12, 27 and Christopher Wolfl comment for this article]. Microdiscectomy by itself qualifies as minimally invasive surgery and does not carry the limitations of the endoscopic approach.

The METRx X-Tube with microscopic visualization technically does not differ significantly from microdiscectomy. The main difference lies in a muscle-splitting rather than subperiosteal approach to the spine. In our opinion the METRx X-Tube system's practical advantages include the possibility to use neurosurgical instruments at hand (without the need to purchase a whole new set). Furthermore, a relatively wide working channel and similarities to the classic microdiscectomy make it fairly easy to learn. Discectomy performed with the system described above gives a good base for more advance training in minimally invasive spinal surgery. With experience a muscle-splitting approach and tubular retractors might be used in far more advanced operations $[26,28]$; they can also facilitate a 'smooth' conversion to surgery with endoscopic visualization.

To sum up, our results do not support definitive conclusions due to the small number of patients. Nonetheless, in our opinion lumbar discectomy with the METRx X-Tube system and operative microscope holds significant advantages without the limitations characteristic of the endoscopic technique.

\section{Conclusions}

The results presented above, due to the small number of patients, do not validate any definitive conclusions. It seems, however, that lumbar discectomy with the METRx X-Tube system and operative microscope holds significant advantages without the limitations characteristic of the endoscopic technique. These advantages include: three-dimensional visualization, the ability to use the instruments a neurosurgeon is familiar with, and a wide range of use in lumbar disc disease and other spinal pathologies within the minimally invasive approach. 


\section{Acknowledgement}

We would like to thank Medtronic Poland Sp. z o.o. for lending the METRx X-Tube operative system.

\section{Disclosure}

The authors report no conflict of interest.

\section{References}

1. Maroon J. Current concepts in minimally invasive discectomy. Neurosurgery 2002; 51: 137-145.

2. Destandau J. A special device for endoscopic surgery of lumbar disc herniation. Neurol Res 1999; 21: 39-42.

3. Destandau J. Technical features of endoscopic surgery for lumbar disc herniation: 191 patients. Neurochirurgie 2004; 50: 6-10.

4. Łysoń T., Mariak Z., Jadeszko M., et al. Results of Destandau microendoscopic lumbar discectomy. Neurol Neurochir Pol 2008; 42: 105-111

5. Foley K., Smith M. Microendoscopic discectomy. Tech Neurosurg 1997; 3: 301-307.

6. Perez-Cruet M., Foley K., Isaacs R., et al. Microendoscopic lumbar discectomy: technical note. Newrosurgery 2002; 51: 129-136.

7. Palmer S. Use of a tubular retractor system in microscopic lumbar discectomy: 1 year prospective results in 135 patients. Neurosurg Focus 2002; 13: 5.

8. Armin S., Holly L., Khoo L. Minimally invasive decompression for lumbar stenosis and disc herniation. Neurosurg Focus 2008; 25: 11

9. Fan S., Fang X., Zhao X., et al. Clinical value of minimally invasive posterior lumbar interbody fusion assisted by X-Tube system in the treatment of low back disorders. Zhonghua Wai Ke Za Zhi 2008; 46: 488-492.

10. Sasaoka R., Nakamura H., Konishi S., et al. Objective assessment of reduced invasiveness in MED compared with conventional one-level laminotomy. Eur Spine J 2006; 15: 577-582.

11. Shin D., Kim K., Shin H., et al. The efficacy of microendoscopic discectomy in reducing iatrogenic muscle injury. $J$ Neurosurg Spine 2008; 8: 39-43.

12. Schizas C., Tsiridis E., Saksena J. Microendoscopic discectomy compared with standard microsurgical discectomy for treatment of uncontained or large contained disc herniations. Neurosurgery 2005; 57: 357-360.

13. Isaacs R., Podichetty V., Fessler R. Microendoscopic discectomy for recurrent disc herniations. Neurosurg Focus 2003; 15: 11.

14. Vogelsang J.P. The translaminar approach in combination with a tubular retractor system for the treatment of far cranio-laterally and foraminally extruded lumbar disc herniations. Zentralbl Neurochir 2007; 68: 24-28.

15. Vogelsang J.P., Maier H. Clinical results and surgical technique for the treatment of extreme lateral lumbar disc herniations: the minimally invasive microscopically assisted percutaneous approach. Zentralbl Neurochir 2008; 69: 35-39.

16. Pirris S., Dhall S., Mummaneni P., et al. Minimally invasive approach to extraforaminal disc herniations at the lumbosacral junction using an operating microscope: case series and review of the literature. Neurosurg Focus 2008; 25: E10.

17. Khoo L., Palmer S., Laich D., et al. Minimally invasive percutaneous posterior lumbar interbody fusion. Neurosurgery 2002; 51 (5 Suppl): 166-171.

18. Palmer S., Turner R., Palmer R. Bilateral decompression of lumbar spinal stenosis involving a unilateral approach with microscope and tubular retractor system. $J$ Neurosurg 2002; 97 (2 Suppl): 213-217.

19. Zhang S., Wang C., Chen H., et al. Preliminary experiences in minimally invasive transforaminal lumbar interbody fusion. Zhonghua Wai Ke Za Zhi 2009; 47: 112-115.

20. Zhou Y., Zhang C., Wang J., et al. Minimally invasive strategies and options for far-lateral lumbar disc herniation. Chin J Traumatol 2008; 11: 259-266.

21. Bagan B., Patel N., Deutsch H., et al. Perioperative complications of minimally invasive surgery (MIS): comparison of MIS and open interbody fusion techniques. Surg Technol Int 2008; 17: 281-286

22. O'Toole J.E., Eichholz K.M., Fessler R.G. Minimally invasive insertion of syringosubarachnoid shunt for posttraumatic syringomyelia: technical case report. Neurosurgery 2007; 61 (5 Suppl): 331-332.

23. Tredway T.L., Musleh W., Christie S.D., et al. A novel minimally invasive technique for spinal cord untethering. Neurosurgery 2007; 60 (2 Suppl): 70-74.

24. Tredway T.L., Santiago P., Hrubes M.R., et al. Minimally invasive resection of intradural-extramedullary spinal neoplasms. Neurosurgery 2006; 58 (1 Suppl): 52-58.

25. Nowitzke A. Assessment of the learning curve for lumbar microendoscopic discectomy. Neurosurgery 2005; 56: 755-762.

26. Parikh K., Tomasino A., Knopman J., et al. Operative results and learning curve: microscope-assisted tubular microsurgery for 1- and 2-level discectomies and laminectomies. Neurosurg Focus 2008; 25: 14 .

27. Righesso O., Falavigna A., Avanzi O. Comparison of open discectomy with microendoscopic discectomy in lumbar disc herniations: results of a randomized controlled trial. Neurosurgery 2007; 61: 545-549.

28. Hsieh P., Koski T., Sciubba D., et al. Maximizing the potential of minimally invasive spine surgery in complex spinal disorders. Neurosurg Focus 2008; 25: 19. 